\title{
Regulatory Effect of Hypoxia-Inducible Factor-1 $\alpha$ on hCG-Stimulated Endothelin-2 Expression in Granulosa Cells from the PMSG-Treated Rat Ovary
}

\author{
Jisen ZHANG ${ }^{1)}$, Zhenghong ZHANG ${ }^{1,2)}$, Yanqing WU'1), Liyun CHEN'1), Qianping LUO'), \\ Jiajie CHEN ${ }^{1)}$, Xiaohong HUANG ${ }^{1)}$, Yong CHENG $^{2)}$ and Zhengchao WANG ${ }^{1)}$ \\ 1) Provincial Key Laboratory for Developmental Biology and Neurosciences, College of Life Sciences, Fujian Normal \\ University, Fuzhou 350007, P.R.China \\ 2) Provincial Research Center for Animal Transgenesis and Biopharming, College of Veterinary Medicine, Yangzhou \\ University, Yangzhou 225009, P. R. China
}

\begin{abstract}
Endothelin (ET)-2 plays a crucial role in ovarian ovulation in mammals. The present study was designed to test the hypothesis that hypoxia-inducible factor (HIF)- $1 \alpha$-mediated transcriptional activation contributes to the increased expression of ET-2 gene in response to hCG in rat ovarian granulosa cells (GCs) during gonadotropin-induced superovulation. By realtime RT-PCR analysis, ET-2 mRNA expression was found to significantly increase in cultured ovarian GCs after treatment with hCG, or even N-carbobenzoxyl-L-leucinyl-L-leucinyl-L-norvalinal (MG-132), while this increased ET-2 mRNA expression could also be blocked by ferrous ammonium sulfate (FAS) under human chorionic gonadotropin (hCG) treatment. Further analysis also found that these changes of ET- 2 mRNA were consistent with HIF-1 $\alpha$ expression or HIF-1 activity, and HIF-1 $\alpha$ inhibitor echinomycin inhibited ovulation in rats. Taken together, these results indicate that ET-2 is transcriptionally activated by hCG through HIF-1 $\alpha$-mediated mechanism in GCs. This HIF- $1 \alpha$-induced transcriptional activation may be one of the important mechanisms mediating the increase of ET-2 expression in GCs during the gonadotropin-induced mammalian ovulatory process in vivo.
\end{abstract}

Key words: Endothelin-2, Granulosa cells, Hypoxia-inducible factor-1 $\alpha$, Rat

(J. Reprod. Dev. 58: 678-684, 2012)

l: female rats, two pituitary gonadotropin hormones, $\mathrm{FSH}$ and $\mathrm{LH}$, control reproductive cyclical events, including ovarian follicle maturation, rupture and release of fertilizable oocytes during a 4-day reproductive cycle in the initial stage of puberty. During each cycle, FSH stimulates a pool of preantral follicles to develop into mature follicles, while the ensuing surge of LH induces ovulation, through LH-activated downstream signaling pathways inthe preovulatory follicles and eventually triggers the release ofoocytes from these follicles $[1,2]$. At present, our understanding of the regulatory mechanisms controlling the growth and final differentiation of a mammalian follicle has advanced exponentially, but our understanding of even the most fundamental pathways is still not complete during these dynamic processes. Endothelin-2 (ET-2) was recently proposed as a granulosa cell-derived contractile signal that facilitates ovulation [3-5].

Endothelin-2 (ET-2) is a small, 21 amino acid peptide that is produced by granulosa cells at the time of ovulation [3]. Expression of mRNA for ET-2, but not ET-1 or ET-3, is dramatically increased in the periovulatory follicle for only a very brief period of time (1-2 h) around ovulation, and blockade of endothelin receptor binding will

Received: May 25, 2012

Accepted: July 16, 2012

Published online in J-STAGE: August 20, 2012

(C)2012 by the Society for Reproduction and Development

Correspondence: Z Wang (e-mail: zcwang@fjnu.edu.cn) delay/inhibit the process of follicular rupture [3]. This rather unique spatial- and temporal-specific pattern of mRNA expression suggests the involvement of direct signaling pathways to accurately coordinate controlled production of this peptide. Therefore, understanding of the regulatory mechanism controlling production of endothelin-2 (ET-2) becomes more and more important for further knowledge of the precise regulatory mechanism of mammalian ovulation.

Given the intrafollicular changes in oxygen concentration during follicular growth and development, the intrafollicular microenvironment is considered to be hypoxic, which stimulates hypoxiainducible factor-1 $\alpha$ expression in GCs. Indeed, the partial pressure of oxygen is reported to decrease with increasing follicular size in women [6] and swine [7]. Furthermore, hCG regulates expression of hypoxiainducible factor (HIF)-1 $\alpha$ in mammalian granulosa-lutein cellsand its responsive genes, which participate in different physiological processes in the ovary $[8,9]$. Overall, several lines ofevidence are consistent with the induction of hypoxic stress within the periovulatory follicle and gonadotropin prior to ovulation. HIF-1, a helix-loop-helix transcriptional factor, which consists of HIF- $1 \alpha$ and HIF-1 $\beta$, has been cloned and characterized as a transcriptional activator of many oxygen-sensitive genes, such as erythropoietin, hemeoxygenases, transferrin, and several glycolytic enzymes [10-14]. It has been indicated that the HIF-1 $\alpha$ is inducibleby a decrease in tissue or cellular $\mathrm{O}_{2}$. HIF-1 $\beta$ is not inducible, but it can be bound to HIF- $1 \alpha$ to form a dimer to activate the transcription of many genes containing cisactinghypoxia-response element (HRE) in their promoter or enhancer 
regions and to regulate their transcriptional expression [15-18].

Hence, the present study was designed to test the hypothesis that HIF-1 mediates the transcription activation of ET-2 in GCs during the ovarian ovulatory process. Using the GCs isolated from the rat ovaries, we determined the effects of hCG and the changes in HIF- $1 \alpha$ levels by pharmacological and molecular interventions on ET-2 mRNA expression in an animal experiment in which rats were treated enchinomycin, HIF-1 molecular inhibitor. These experiments will provide direct evidence showing that ET-2 is transcriptionally activated byan HIF-1-mediated mechanism in GCs under hCG and the potential role of HIF-1 $\alpha$-ET-2 signaling in the ovarian ovulatory process.

\section{Materials and Methods}

\section{Animals}

Immature female Sprague-Dawley rats were purchased from Wushi Experimental Animal Supply (Fuzhou, China). The animals were maintained under a 14-h light/10-h dark schedule with continuous supply of chow and water. Follicular development was induced by treatment of 23-25-day-old rats with 10 IU pregnant mare serum gonadotropin (PMSG, Sigma, St. Louis, MO, USA). Animals were sacrificed after $48 \mathrm{~h}$ of PMSG treatment to collect ovaries and GCs for in vitro culture experiments. The experimental protocol was approved in accordance with the Guide for the Care and Use of Laboratory Animals prepared by the Institutional Animal Care and Use Committee, Fujian Normal University.

\section{Isolation and culture of GCs}

Ovaries were collected from gonadotropin-primed rats, and granulosa cells were isolated by follicular puncture. Briefly, granulosa cells were collected in a culture medium, DMEM/F-12 medium (GIBCO, No.11330, Grand Island, NY, USA) containing 5\% fetal bovine serumand $20 \mu \mathrm{g} / \mathrm{ml}$ gentamicin. Cells were washed three times in the culture medium, plated on serum-coated six-well plates at a density of approximately $1 \times 10^{6}$ cells per well and cultured in a cell culture incubator with a humidified atmosphere of $5 \% \mathrm{CO}_{2}$ in air at $37.5 \mathrm{C}$. To examine the induction of mRNA for ET-2 and HIF- $1 \alpha$ by treatment with an ovulatory dose (5 IU) of human chorionic gonadotropin (hCG, Sigma) in vitro, granulosa cells were collected from ovaries of gonadotropin-primed rats sacrificed at $48 \mathrm{~h}$ after PMSG and cultured with/without 5 IU hCG (final concentration of $100 \mathrm{ng} / \mathrm{ml}$ in medium) and other reagents for $6 \mathrm{~h}$. All cultures were performed in duplicate and replicated 3 times on different days. All these cell samples were examined by RT-PCR and Western blot.

\section{RNA extraction and quantitative RT-PCR analysis of ET-2} and HIF-1 $\alpha$ mRNA

Total RNA was extracted using TRIzol solution (Life Technologies, Rockville, MD, USA) and then reverse-transcribed (cDNA Synthesis Kit;Bio-Rad, Hercules, CA, USA). The reverse-transcribed products were amplified using a TaqMan Gene Expression Assays kit (Applied Biosystems, Foster, CA, USA). A kit fordetecting the levels of $18 \mathrm{~S}$ ribosomal RNA was used as anendogenous control. The relative gene expressions were calculatedin accordance with the $\Delta \Delta \mathrm{Ct}$ method. Relative mRNA levels were expressed as $2^{-\Delta \Delta C t}$ values.
Western blot analysis of HIF-1 $\alpha$ protein levels in cell extracts

The cell samples treated above were used to examine HIF- $1 \alpha$ protein levels by Western blot. Protein concentrations were determined bya Bio-Rad assay with bovine serum albumin standards. Twenty micrograms of GC protein samples were subjected to $8 \%$ SDS-PAGE gel electrophoresis and then electrophoretically transferred onto a PVDF membrane. The membrane was washed and probed with 1:500 specific anti-HIF-1 $\alpha$ antibody (1:500, Abcom, Cambridge, MA, USA) overnight at 4C. After washing, the membranes were incubated with HRP-labeled goat anti-mouse $\operatorname{IgG}$ (1:5000, Novus Biologicals, Littleton, CO, USA) for $60 \mathrm{~min}$ at room temperature, and then the film was developed to obtain the images. To detect the immunoblotting signal, $2 \mathrm{ml}$ of enhanced chemiluminescence detection solution was added, and the membrane was wrapped and exposed to Kodak OMAT film (Xiamen, China).

\section{Transfection of HIF-1 $\alpha$ siRNA}

When cell fusion is approximately $85 \%$, transfection of siRNA was performed using the siLentFect Lipid Reagent (Bio-Rad) according to the manufacturer's instructions. For a $10 \mathrm{~cm}$ dish, 200 pmoles of siRNA was used. After $5 \mathrm{~h}$ incubationin transfection reagent, the cells were switched to normal mediumfor an additional $16 \mathrm{~h}$ and were then ready for the experiment. The sequence of HIF- $1 \alpha$ siRNA was: sense, 5'-GGAAAGAGACUCAUAGAAA-3', antisense, 5'-UUUCUAUGACUCUCUUUCC-3, (Sigma-Aldrich, St. Louis, MO, USA). A scrambled small RNA (sense, 5'-UUC UCC GAA CGU GUC ACG U-3', antisense, 5'-ACG UGA CAC GUU CGG AGA A-3, QIAGEN, Valencia, CA, USA), which was confirmed to be a non-silencing double-stranded RNA, was used as a control for siRNA experiments.

\section{Decoy of HIF-1 $\alpha$}

It has been demonstrated that HIF- $1 \alpha$ activates gene expression by binding to a promoter or an enhancer site, HRE. This ciselement contains a - $\boldsymbol{C} \boldsymbol{G} \boldsymbol{T} \boldsymbol{G}$-consensus sequence. A standardfluorescein-attached HRE containing oligodeoxynucleotides (ODN)was synthesized with sequences of 5'-GCCCTACGTGCTGTCTCA3'(sense) and 5'-TGAGACA GCACGTAGGGC-3' (antisense), and another containing scrambled ODN was synthesized with sequences of 5'-GCCCTTACAAC TGTCTCA-3' (sense) and 5'-GAGACAGTTGTAAGGGC-3'(antisense). To make doublestrand ODN (dsODN), both sense and antisense ODNs $(100 \mu \mathrm{M}$ in TE, $\mathrm{pH}$ 8.0) were heated at $95 \mathrm{C}$ for $5 \mathrm{~min}$ and then cooled slowly down to room temperature. These dsODNs were wrapped by using cationic liposomes (Avanti Polar Lipids, Alabaster, AL, USA) and transfected into GCs as described by the manufacturer. dsDNA $(10 \mu \mathrm{g})$ was first mixed with $50 \mu \mathrm{l}$ of liposome and then added to $5 \mathrm{ml}$ of serum-free incubation medium.

\section{Preparation of cell nuclear extracts and analyses of HIF banding activity}

Cell nuclear protein was prepared using a nuclear extract kit (Panomics, Fremont, CA, USA) and HIF-1 $\alpha$ binding activities in the nuclear extracts were detected using an ELISA-based HIF binding kit (Panomics). The ELISA-based HIF binding assay kit provides a fast, sensitive, and specific measurement of the HIF-1 binding activities. 


\section{Gonadotropin-induced superovulation}

To induce superovulation, rats were treated with 10 IU PMSG and $5 \mathrm{IU}$ hCG after $48 \mathrm{~h}$ to induce the ovulatory process. In the echinomycin-treated groups, rats ( $\mathrm{n}=6$ for each treatment group) were IP injected with either vehicle or a fixed dose of echinomycin (1 mg/ $\mathrm{kg}$ body weigh, BioViotic, Dransfeld, Germany) at $6 \mathrm{~h}$ after hCG. Ovaries were collected from each group at $11 \mathrm{~h}$ after hCG treatment for RT-PCR analysis and at $20 \mathrm{~h}$ after hCG treatment for fixing in $4 \%$ paraformaldehyde (PFA) $24 \mathrm{~h}$ at room temperature with gentle rocking. These tissues were then embedded in paraffin and sectioned at $5 \mu \mathrm{m}$. The ovarian sections were stained with hematoxylin and eosin for histological examination.

\section{Statistics}

Data are presented as means \pm SE. The significance of differences in mean values within and between multiple groups was evaluated using a one-way ANOVA, followed by a Tukey's multiple range test. The student's $t$ test was used to evaluate statistical significance of differences between two groups. $\mathrm{P}<0.05$ was considered statistically significant.

\section{Results}

Effects of hCG on ET-2 mRNA and HIF-1 $\alpha$ mRNA expression in GCs

Our results showed that in GCs hCG significantly induced ET-2 mRNA expression ( $\mathrm{P}<0.05$, Fig. 1A), which is consistent with HIF-1 $\alpha$ mRNA changes $(\mathrm{P}<0.05$, Fig. $1 \mathrm{~B})$.

\section{Effects of FAS on ET-2 mRNA and HIF-1 $\alpha$ mRNA expression in GCs}

FAS is an inhibitor of HIF-1 $\alpha$ expression, which was used to determine the effect of FAS on HIF- $1 \alpha$ mRNA and ET-2 mRNA levels after hCG treatment. The present results showed that FAS treatment can block the hCG-induced increase of HIF- $1 \alpha$ mRNA $(\mathrm{P}<0.05$, Fig. 1B), and in parallel, ET-2 mRNA ( $\mathrm{P}<0.05$, Fig. 1A) expression was also decreased in these cells by FAS treatment, implying that hCG may induce the increase of ET-2 through HIF-1 $\alpha$ signaling.

\section{Effects of HIF-1 $\alpha$ siRNA on ET-2 mRNA and HIF-1 $\alpha$ mRNA expression in GCs}

In the present study, we also performed experiments to observe whether HIF-1 $\alpha$ siRNAblocks the level of ET-2 mRNA induced by hCGin GCs. The HIF- $1 \alpha$ siRNA efficiency was examined, and it was found to works well $(\mathrm{P}<0.05$, Fig. 2). HIF- $1 \alpha$ siRNA transfection significantly blocked the hCG-induced HIF-1 $\alpha$ mRNA increase $(\mathrm{P}<0.05$, Fig. $2 \mathrm{~B})$, while a significant decreasein ET- 2 mRNA $(\mathrm{P}<0.05$, Fig. $2 \mathrm{~A})$ was found in GCs transfected with HIF- $1 \alpha$ siRNA compared with the hCG only treatment.

\section{Effects of MG-132 on ET-2 mRNA, HIF-1 $\alpha$ mRNA and HIF-} $1 \alpha$ protein expression in GCs

In order to further confirm our findings, we also used the HIF- $1 \alpha$ degradation inhibitor MG-132 to block the protease pathway and then examined the effect on ET-2 mRNA. A significant increase in ET-2 mRNA levels $(\mathrm{P}<0.05$, Fig. 3A) was found in these cells
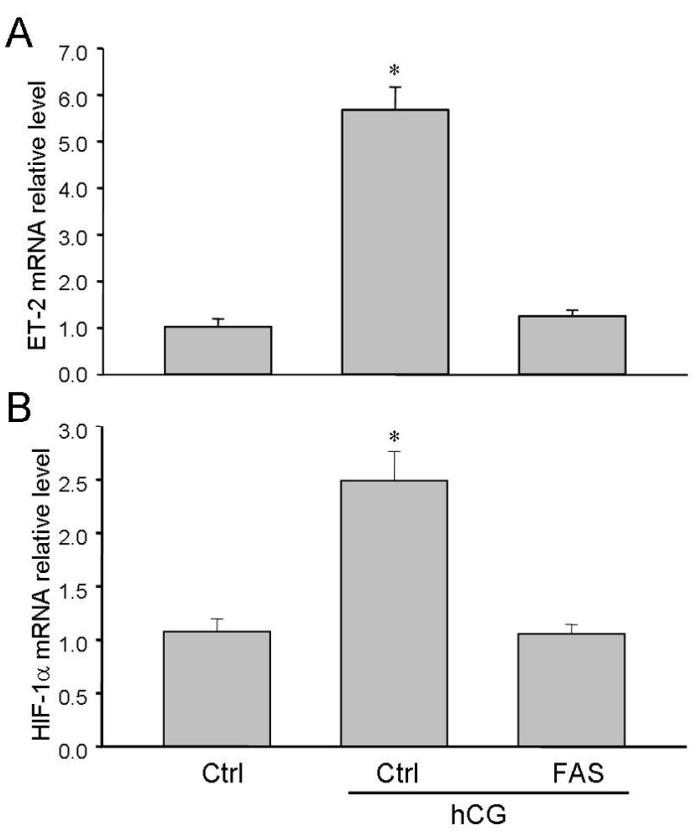

Fig. 1. Effects of hCG and FAS on ET-2 mRNA and HIF- $1 \alpha$ mRNA expression in GCs. Panel A: the relative mRNA levels of ET-2 by real-time RT-PCR analysis. Panel B: the relative mRNA levels of HIF- $1 \alpha$ by real-time RT-PCR analysis. Each value represents the mean \pm SE. One-way analysis of variance (ANOVA) was used to analyze the data. The asterisk denotes significant values $(\mathrm{P}<0.05)$ by Tukey's multiple range test. $\mathrm{n}=6$ batches of cells. $\mathrm{hCG}=$ human chorionic gonadotropin, $\mathrm{FAS}=$ ferrous ammonium sulfate.

treated with MG-132, even without hCG treatment. Compared with the changes of HIF- $1 \alpha$ protein expression ( $\mathrm{P}<0.05$, Fig. 4 ), HIF- $1 \alpha$ mRNA levels (Fig. 3B) were not altered dramatically by this protease inhibition because MG-132 primarily acted to block the degradation of HIF-1 $\alpha$ protein.

Effects of HIF-1 $\alpha$ decoy on ET-2 mRNA, HIF-1 $\alpha$ protein and HIF-1 activity in response to $h C G$ in GCs

In order to further confirm our hypothesis that HIF-1 $\alpha$ directly regulated ET-2 gene transcription, we used these cells transfected with the HIF-1 $\alpha$ decoy oligodeoxy nucleotides to determine the effect of dsODNs on ET-2 mRNA expression in response to hCG. The results showed that hCG induced ET- 2 mRNAexpression $(\mathrm{P}<0.05$, Fig. 5), while this hCG-induced increase in ET-2 mRNA levels was depressed in the cells transfected with specific dsODN [dsODN $(+)]$ containing 5'-CGTG-3' ( $\mathrm{P}<0.05$, Fig. 5). However, this decoy of HIF-1 had no effecton HIF-1 $\alpha$ protein expression in response to hCG in these cells (Fig. 6), compared with their inhibitory effects on HIF-1 binding activity ( $\mathrm{P}<0.05$, Fig. 7 ). As a control, scrambled dsODN [dsODN(-)] without 5'-CGTG-3'was used to transfect GCs, but it had no effect on the increase in ET-2 mRNA levels induced by hCG (Fig. 5). Together, it was clearly demonstrated that the decoy of HIF-1by its specific binding to dsODN blocked the induction of ET-2 mRNA. 
A

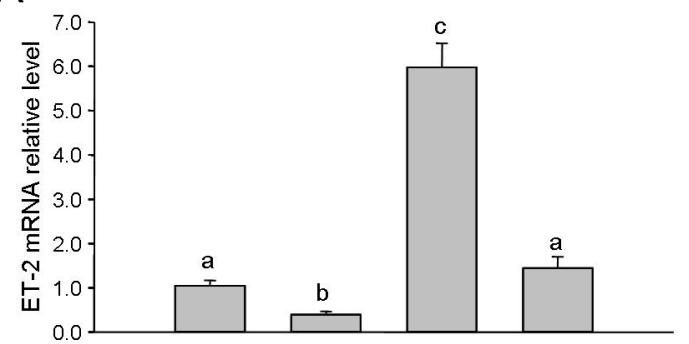

B

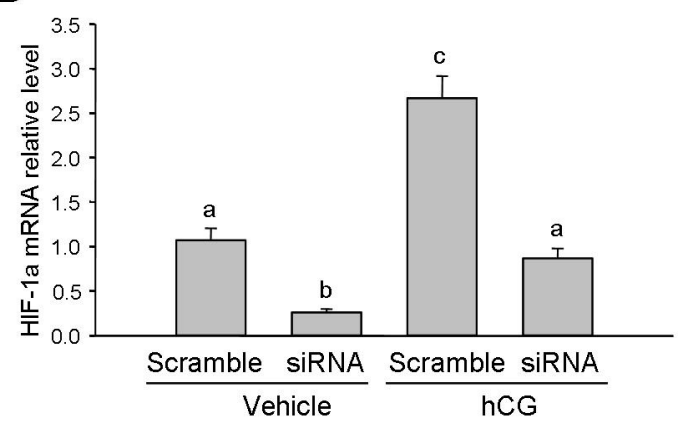

Fig. 2. Effects of HIF- $1 \alpha$ siRNA on ET- 2 mRNA and HIF- $1 \alpha$ mRNA expression in GCs. Panel A: the relative mRNA levels of ET-2 by real-time RT-PCR analysis. Panel B: the relative mRNA levels of HIF- $1 \alpha$ by real-time RT-PCR analysis. Each value represents the mean \pm SE. One-way analysis of variance (ANOVA) was used to analyze the data. Different superscripts denote significant values $(\mathrm{P}<0.05)$ by Tukey's multiple range test. $\mathrm{n}=6$ batches of cells. Scramble $=$ scramble RNA, siRNA $=$ HIF-1 $\alpha$ siRNA, vehicle $=$ dimethyl sulfoxide.

A

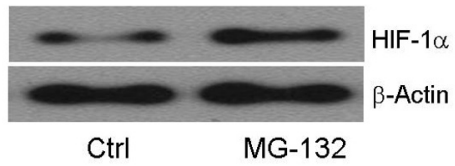

B

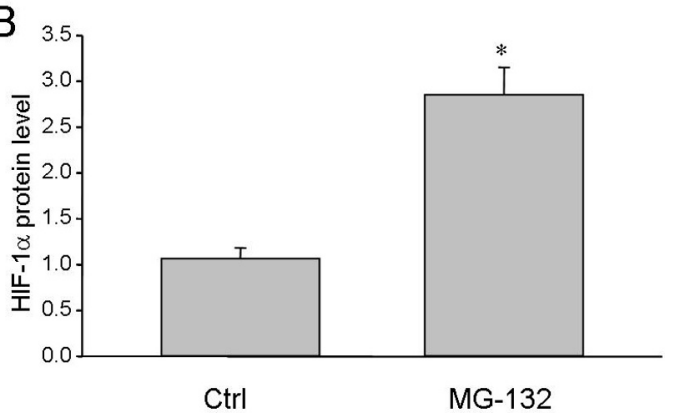

Fig. 4. Effects of MG-132 on HIF-1 $\alpha$ protein expression in GCs. Panel A: representative ECL gel documents of Western blot analyses depicting the protein level of HIF-1 $\alpha$. Panel B: summarized intensities of HIF-1 $\alpha$ blots normalized to the control. The asterisk denotes significant values $(\mathrm{P}<0.05)$ by Tukey's multiple range test. $\mathrm{n}=6$ batches of cells. $\mathrm{Ctrl}=$ vehicle, MG-132= $N$-carbobenzoxyl-L-leucinyl-L-leucinylL-norvalinal.
A

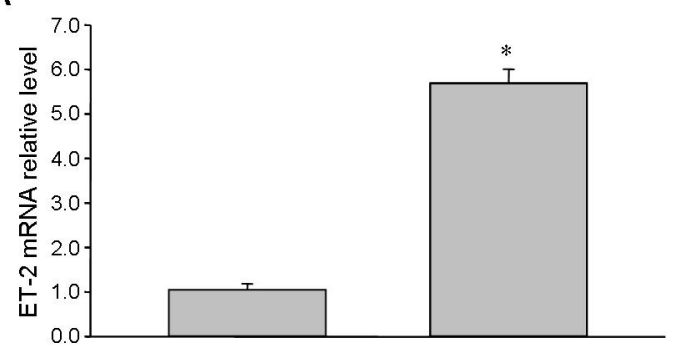

B

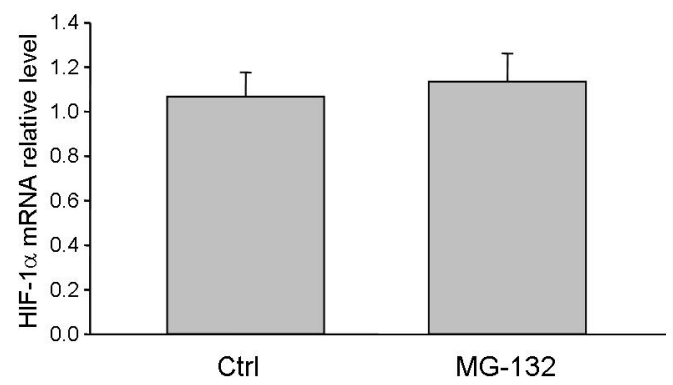

Fig. 3. Effects of MG-132 on ET-2 mRNA and HIF-1 $\alpha$ mRNA expression in GCs. Panel A: the relative mRNA levels of ET-2 by real-time RT-PCR analysis. Panel B: the relative mRNA levels of HIF-1 $\alpha$ by real-time RT-PCR analysis. Each value represents the mean \pm SE. One-way analysis of variance (ANOVA) was used to analyze the data. The asterisk denotes significant values $(\mathrm{P}<0.05)$ by Tukey's multiple range test. $\mathrm{n}=6$ batches of cells. $\mathrm{Ctrl}=$ vehicle, $\mathrm{MG}-132=$ $\mathrm{N}$-carbobenzoxyl-L-leucinyl-L-leucinyl-L-norvalinal.

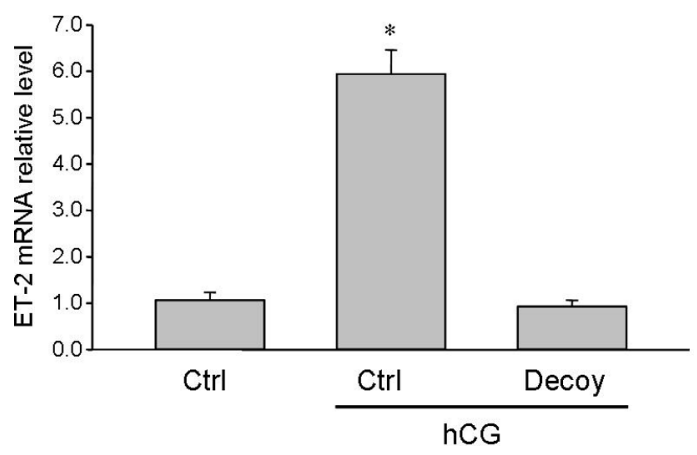

Fig. 5. Effects of transfection of HIF-1 $\alpha$ decoy ODNs on ET-2 mRNA expression in response to hCG in GCs. The relative mRNA levels of ET-2 by real-time RT-PCR analysis. The asterisk denotes significant values $(\mathrm{P}<0.05)$ by Tukey's multiple range test. $n=6$ batches of cells.

Effect of the HIF-1-specific inhibitor echinomycin on ovarian ovulation in rats that underwent a superovulatory protocol

ET-2 plays an important role in ovarian follicular rupture, and in order to determine whether the blockade of ovulation in echinomycintreated rats occursdue to a defect in follicular rupture, we examined the histology of the ovaries of untreated and echinomycin-treated rats subjected to a superovulation protocol. Histological examination 
A
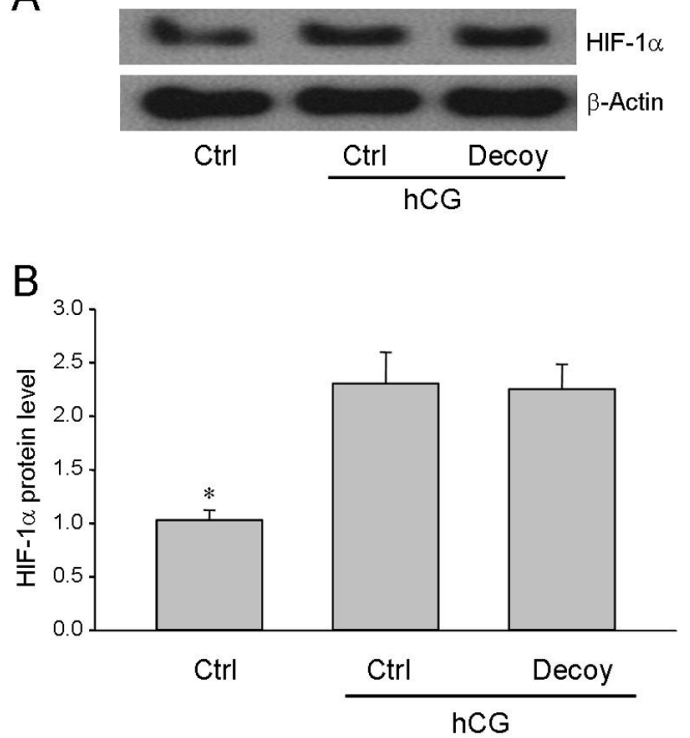

Fig. 6. Effects of HIF- $1 \alpha$ decoy ODNs transfection on HIF- $1 \alpha$ expression in response to hCG in GCs. Panel A: representative ECL gel documents of Western blot analyses depicting the protein level of HIF-1 $\alpha$. Panel B: summarized intensities of HIF- $1 \alpha$ blots normalized to the control. The asterisk denotes significant values $(\mathrm{P}<0.05)$ by Tukey's multiple range test. $\mathrm{n}=6$ batches of cells.

of the control ovaries at $20 \mathrm{~h}$ after hCG revealed that they were primarily comprised of corpora lutea, indicating that ovulatory follicles had ruptured and undergone luteinization (Fig. 8). In the echinomycin-treated rats, the ovaries harbored numerous unruptured follicles with trapped oocytes. These results implied that inhibition of HIF-1 activity by echinomycin impaired ovulation by preventing rupture of the preovulatory follicles through the ET-2 pathway.

\section{Effect of echinomycin on HIF-1 $\alpha$ and ET-2 mRNA}

expression levels in the ovaries with gonadotropin-induced superovulation

To further confirm that HIF-1 $\alpha$-ET-2 signaling is involved in gonadotropin-induced superovulation, immature rats were given either vehicle or $1 \mathrm{mg} / \mathrm{kg}$ body weigh echinomycin at $6 \mathrm{~h}$ after hCG treatment, and ovaries were collected at $11 \mathrm{~h}$ after hCG treatment for further investigation. By real-time PCR analysis, ET-2 mRNA expression was found to significantly decrease in the ovaries treated with echinomycin ( $\mathrm{P}<0.05$, Fig. 9A), while HIF-1alpha mRNA (Fig. 9B) showed no obvious changes, implying that ET-2 may play a crucial role in ovarian ovulation in mammals, which is consistent with previous results.

\section{Discussion}

The results of real-time RT-PCR analysis clearly demonstrated that ET-2 mRNA expression increased significantly under hCG treatment, which is consistent with previous reports $[3,4,17]$. Furthermore, the hCG-induced increase of HIF-1 $\alpha$ implied that transcriptional

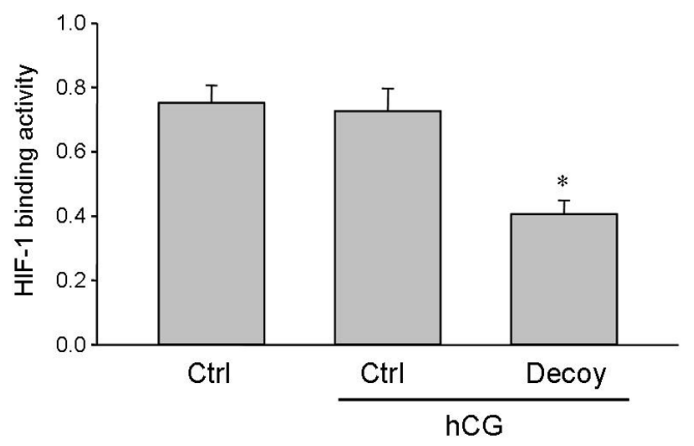

Fig. 7. Effects of transfection of HIF-1 $\alpha$ decoy ODNs on HIF-1 binding activity in response to hCG in GC. HIF-1 binding assay of the nuclear extracts from different GC treatment groups. The asterisk denotes significant values $(\mathrm{P}<0.05)$ by Tukey's multiple range test. $\mathrm{n}=6$ batches of cells.
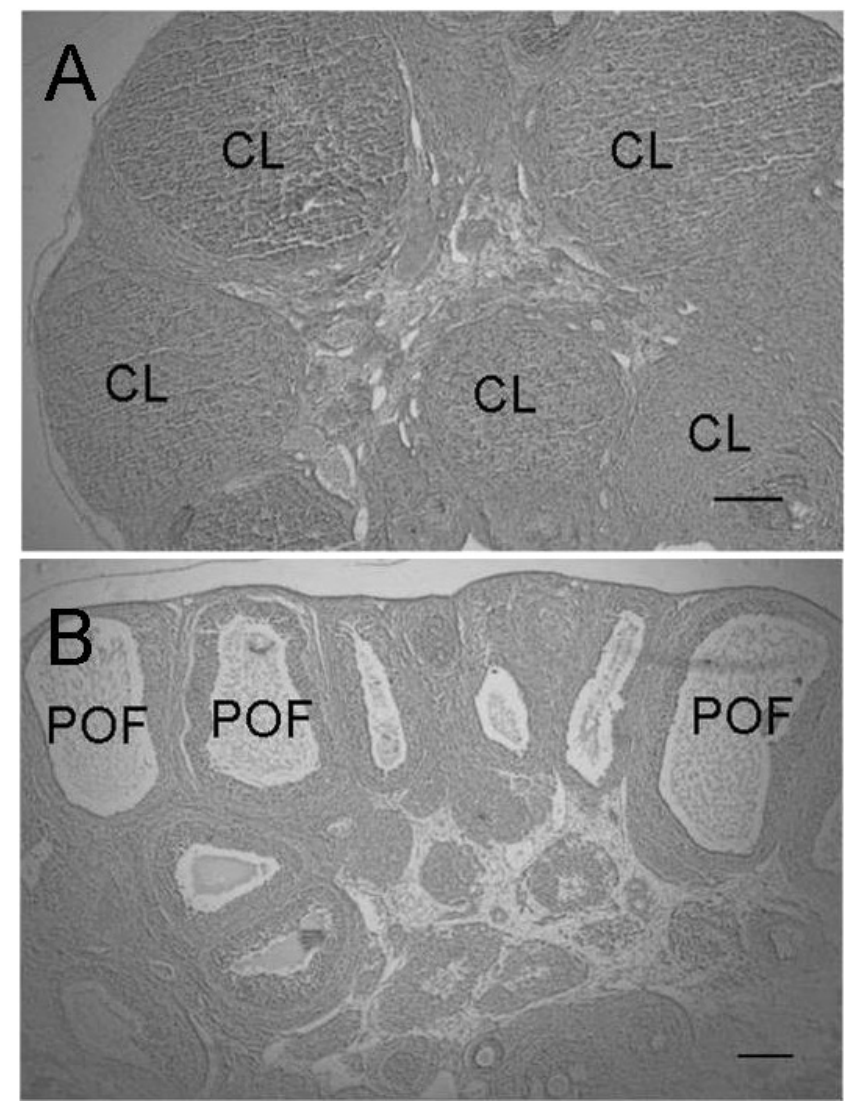

Fig. 8. Effect of the HIF-1-specific inhibitor echinomycin on ovarian ovulation in rats that underwent a superovulatory protocol. Inhibition of follicular rupture with echinomycin treatment. A is the control group, and B is the echinomycin treated group. Rats ( $\mathrm{n}=6$ for each treatment group) were subjected to PMSG and hCG-induced superovulation, and were IP injected with either vehicle (dimethyl sulfoxide) or echinomycin $(10 \mathrm{mg} / \mathrm{kg}$ body weight) at $6 \mathrm{~h}$ after hCG. The ovaries were collected at $20 \mathrm{~h}$ after hCG. The tissues were fixed in $4 \%$ paraformaldehyde, embedded in paraffinand sectioned. The ovarian sections were stained with hematoxylin and eosin, and visualized under a light microscope. Note that the ovary from the vehicle-treated rat harbors numerous corpora lutea $(\mathrm{CL})$, whereas the ovary from the echinomycintreated rat shows many unruptured preovulatory follicles (POF). 


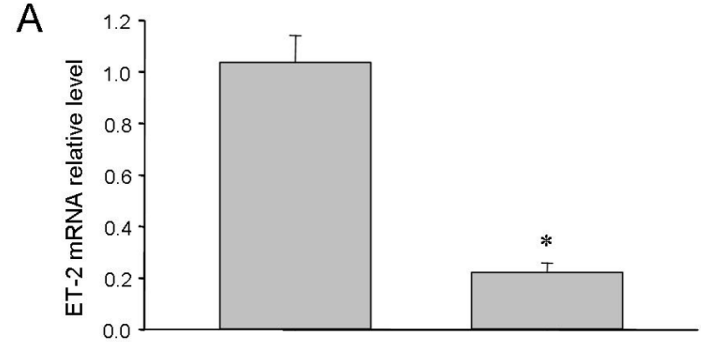

$\mathrm{B}$

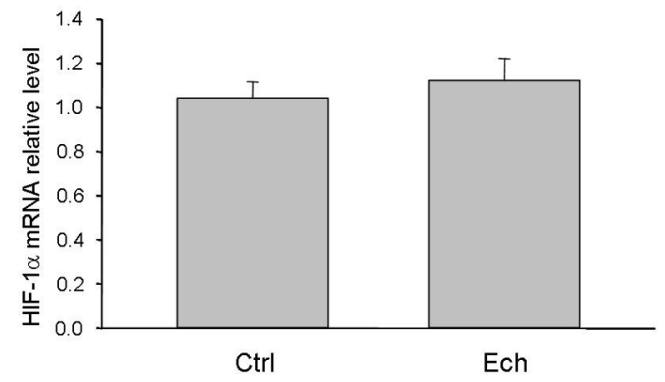

Fig. 9. Effects of echinomycin on ET-2 mRNA and HIF-1alpha mRNA expression in rat ovaries with a superovulatory protocol. Panel A: the relative mRNA levels of ET-2 by realtime RT-PCR analysis. Panel B: the relative mRNA levels of HIF-1alpha by real-time RT-PCR analysis. Each value represents the mean $\pm \mathrm{SE}$. The student's $t$ test was used to evaluate the statistical significance of differences between two groups. The asterisk denotes significant values $(\mathrm{P}<0.05)$. Ech $=$ echinomycin .

regulation of ET-2 may be through activation of HIF-1 $\alpha$, while this hCG-induced upregulation of ET-2 mRNA was blocked by HIF- $1 \alpha$ inhibition with FAS in GCs, suggesting that this transcription factor is probably involved in transcriptional activation of ET-2 gene. To further determine the role of HIF-1 $\alpha$ in the activation of ET-2 transcription, HIF-1 $\alpha$ siRNA were used to address whether silencing HIF-1 $\alpha$ depresses ET-2 mRNA expression in GCs induced by hCG. It was found that HIF- $1 \alpha$ siRNA markedly decreased HIF- $1 \alpha$ mRNA levels and resulted in the blockage of ET- 2 mRNA induced by hCG in GCs. These results further indicated that HIF-1 $\alpha$ takes part in ET-2 transcription in GCs.

Many studies have indicated that HIF-1 $\alpha$ is also regulated at the post-mRNA level and that the ubiquitin-proteasome system is a primary protease system responsible for the degradation of HIF-1 $\alpha$, but HIF-1 $\alpha$ mRNA was also found to increase in response to hCG in vivo in mice [19-23]. To further examine whether the ubiquitinproteasome system has an important contribution to the regulation of intracellular HIF- $1 \alpha$ levels and thereby to the transcriptional activation of downstream genes, we therefore used the HIF-1 $\alpha$ degradation inhibitor MG-132 to block the protease pathway and then examined the effect on ET-2 mRNA [20]. ET-2 transcriptions were found to increase markedly when GCs were treated with MG-132. Because MG-132 primarily acted to block the degradation of HIF-1 $\alpha$ protein, HIF- $1 \alpha$ mRNA levels were not altered dramatically by this protease inhibition. This increase in ET-2 mRNA levels associated with the increase in HIF-1 $\alpha$ protein suggests that transcriptional regulation of the ET-2 gene primarily requires a structural or functional integrity of the HIF- $1 \alpha$ protein in GCs.

In addition to these pharmacological and siRNA interventions, we also used a molecular decoy approach to determine the direct role of HIF- $1 \alpha$ in the transcriptional regulation of the ET- 2 gene. The present results demonstrated that HIF-1 activity in GCs transfected with a dsODN containing an HIF-1 binding site, 5'-CGTG-3', decreased significantly and that the ET mRNA level increased to a much lesser extent under hCG treatment in transfected cells than those in control cells, because this anti-gene therapy strategy can decoy and thereby block the binding of transcription factors to their binding sites in promoter or enhancer regions by introducing a synthesized dsODN containing a binding cis element [24]. These results provide direct evidence that using cis-element oligodeoxy nucleotide transfection to specifically decoy HIF-1 $\alpha$ and block HIF-1 binding activity, attenuated the increase mRNA expression of ET-2 in response to hCG, which further supports our hypothesis that HIF-1 mediates the transcriptional activation of the ET-2 gene.

Finally, we used animal experiments to determine the HIF$1 \alpha$-ET-2 signaling pathway participating in biological events and precise mechanisms of the ovarian ovulatory process in mammals. The functions of HIF-1 $\alpha$ in normal physiology are still less clear; however, in the present study, we report that HIF-1 $\alpha$ regulates the ovulatory process via its target gene signaling, like ET-2, which is involved in this physiological process. PMSG-induced estradiol may also participate in the ovarian process via binding of the promoter region of HIF-1 $\alpha$ target genes to enhance their mRNA levels [15, 16]. HIF- $1 \alpha$ is a member of the basic-Helix-Loop-Helix-PAS family of transcription factors, which are expressed in many tissues and serve as critical regulators of these tissues' responses to changes in oxygen levels and gonadotropin stimulations [11-13]. Echinomycin is a sequence-specific DNA-binding agent that hinders the binding of an HIF-1 heterodimer to HRE, inhibiting the expression of the targets. In rats undergoing gonadotropin-induced ovulation, blockage of HIF activity by this small molecular inhibitor, enchinomycin, profoundly impaired the rupture of the preovulatory follicles, thereby drastically reducing the number of released eggs during ovulation.

In summary, the present study is the firstto provide direct evidence indicating that ET-2 expression in GCs is transcriptionally regulated via an HIF-1 $\alpha$ pathway under hCG treatment. This hCG-induced transcriptional activation may be one of the important mechanisms mediating increased expression of ET-2 during ovulation in the mammalian ovary. Furthermore, HIF-1 $\alpha$ antagonism affords an opportunity for the development of novel treatments for fertility control and for some types of ovarian dysfunction, particularly those conditions characterized by pathological angiogenesis and excessive vascular permeability, such as polycystic ovarian syndrome (PCOS), ovarian hyperstimulation syndrome (OHSS) and ovarian neoplasia [25-29].

\section{Acknowledgments}

This study was supported bythe National Natural Science Foundation of China (No. 31101032 and 31040084), Doctoral Foundation of the Ministry of Education in China (No.20113503120002), Innovative Research Project of the National Biology Experiment Center (No. 2011LS017), Fujian Provincial Natural Science Foun- 
dation (No. 2011J01144) and Fujian Provincial Science and Technology Projects of the Department of Education (No. AJ11041).

\section{References}

1. Richards JS. Hormonal control of gene expression in the ovary. Endocr Rev 1994; 15: 725-751. [Medline]

2. Richards JS, Russell DL, Ochsner S, Espey LL. Ovulation: new dimensions and new regulators of the inflammatory-like response. Annu Rev Physiol 2002; 64: 69-92. [Medline]

3. Ko C, Gieske MC, Al-Alem L, Hahn Y, Su W, Gong MC, Iglarz M, Koo Y. Endothelin-2 in ovarian follicle rupture. Endocrinology 2006; 147: 1770-1779. [Medline]

4. Al-Alem L, Bridges PJ, Su W, Gong MC, Iglarz M, Ko C. Endothelin-2 induces oviductal contraction via endothelin receptor subtype A in rats. J Endocrinol 2007; 193: 383-391. [Medline]

5. Na G, Bridges PJ, Koo Y, Ko C. Role of hypoxia in the regulation of periovulatory EDN2 expression in the mouse. Can J Physiol Pharmacol 2008; 86: 310-319. [Medline]

6. Fischer B, Kunzel W, Kleinstein J, Gips H. Oxygen tension in follicular fluid falls with follicle maturation. Eur J Obstet Gynecol Reprod Biol 1992; 43: 39-43. [Medline]

7. Basini G, Bianco F, Grasselli F, Tirelli M, Bussolati S, Tamanini C. The effects of reduced oxygen tension on swine granulosa cell. Regul Pept 2004; 120: 69-75. [Medline]

8. Herr D, Keck C, Tempfer C, Pietrowski D. Chorionic gonadotropin regulates the transcript level of VHL, p53, and HIF-2alpha in human granulosa lutein cells. Mol Reprod Dev 2004; 69: 397-401. [Medline]

9. Zhang Z, Yu D, Yin D, Wang Z $\mathbf{Z}$. Activation of PI3K/mTOR signaling pathway contributes to induction of vascular endothelial growth factor by $\mathrm{hCG}$ in bovine developing luteal cells. Anim Reprod Sci 2011; 125: 42-48. [Medline]

10. Wang GL, Semenza GL. Desferrioxamine induces erythropoietin gene expression and hypoxia-inducible factor 1 DNA-binding activity: implications for models of hypoxia signal transduction. Blood 1993; 82: 3610-3615. [Medline]

11. Wang GL, Semenza GL. Purification and characterization of hypoxia-inducible factor 1 . J Biol Chem 1995; 270: 1230-1237. [Medline]

12. Wang GL, Semenza GL. Characterization of hypoxia-inducible factor 1 and regulation of DNA binding activity by hypoxia. J BiolChem 1993; 268: 21513-21518. [Medline]

13. Wang GL, Jiang BH, Rue EA, Semenza GL. Hypoxia-inducible factor 1 is a basic-helixloop-helix-PAS heterodimer regulated by cellular O2 tension. Proc Natl Acad Sci USA 1995; 92: 5510-5514. [Medline]

14. Wenger RH, Rolfs A, Marti HH, Guenet JL, Gassmann M. Nucleotide sequence, chromosomal assignment and mRNA expression of mouse hypoxia-inducible factor-1 alpha. Biochem Biophys Res Commun 1996; 223: 54-59. [Medline]

15. Kazi AA, Jones JM, Koos RD. Chromatin immunoprecipitation analysis of gene expression in the rat uterus in vivo: estrogen-induced recruitment of both estrogen receptor alpha and hypoxia-inducible factor 1 to the vascular endothelial growth factor promoter. Mol Endocrinol 2005; 19: 2006-2019. [Medline]

16. Kazi AA, Koos RD. Estrogen-induced activation of hypoxia-inducible factor-1alpha, vascular endothelial growth factor expression, and edema in the uterus are mediated by the phosphatidylinositol 3-kinase/Akt pathway. Endocrinology 2007; 148: 2363-2374 [Medline]

17. Molitoris KH, Kazi AA, Koos RD. Inhibition of oxygen-induced hypoxia-inducible factor-1alpha degradation unmasks estradiol induction of vascular endothelial growth factor expression in ECC-1 cancer cells in vitro. Endocrinology 2009; 150: 5405-5414. [Medline]

18. Nishimura R, Okuda K. Hypoxia is important for establishing vascularization during corpus luteum formation in cattle. J Reprod Dev 2010; 56: 110-116. [Medline]

19. Wiener CM, Booth G, Semenza GL. In vivo expression of mRNAs encoding hypoxiainducible factor 1. Biochem Biophys Res Commun 1996; 225: 485-488. [Medline]

20. Huang LE, Gu J, Schau M, Bunn HF. Regulation of hypoxia-inducible factor lalpha is mediated by an $\mathrm{O} 2$-dependent degradation domain via the ubiquitin-proteasome pathway. Proc Natl Acad Sci USA 1998; 95: 7987-7992.

21. Kallio PJ, Wilson WJ, O'Brien S, Makino Y, Poellinger L. Regulation of the hypoxiainducible transcription factor 1alpha by the ubiquitin-proteasome pathway. $J$ Biol Chem 1999; 274: 6519-6525. [Medline]

22. Kim J, Bagchi IC, Bagchi MK. Signaling by hypoxia-inducible factors is critical for ovulation in mice. Endocrinology 2009; 150: 3392-3400. [Medline]

23. Kim J, Bagchi IC, Bagchi MK. Control of ovulation in mice by progesterone receptorregulated gene networks. Mol Hum Reprod 2009; 15: 821-828. [Medline]

24. Morishita R, Higaki J, Tomita N, Ogihara T. Application of transcription factor "decoy" strategy as means of gene therapy and study of gene expression in cardiovascular disease. Circ Res 1998; 82: 1023-1028. [Medline]

25. Seeber LM, Horree N, Vooijs MA, Heintz AP, van der Wall E, Verheijen RH, van Diest PJ. The role of hypoxia inducible factor-1alpha in gynecological cancer. Crit Rev Oncol Hematol 2011; 78: 173-184. [Medline]

26. Galanis A, Pappa A, Giannakakis A, Lanitis E, Dangaj D, Sandaltzopoulos R. Reactive oxygen species and HIF-1 signalling in cancer. Cancer Lett 2008; 266: 12-20. [Medline]

27. Quintero M, Mackenzie N, Brennan PA. Hypoxia-inducible factor 1 (HIF-1) in cancer Eur J Surg Oncol 2004; 30: 465-468. [Medline]

28. Miyazawa M, Yasuda M, Fujita M, Hirasawa T, Kajiwara H, Hirabayashi K, Ogane N, Shimizu M, Asanuma H, Murakami M, Takekoshi S, Mikami M, Osamura RY. Association of hypoxia-inducible factor-1 expression with histology in epithelial ovarian tumors: a quantitative analysis of HIF-1. Arch Gynecol Obstet 2009; 279: 789-796. [Medline]

29. Miyazawa M, Yasuda M, Fujita M, Hirabayashi K, Hirasawa T, Kajiwara H, Muramatsu T, Miyazaki S, Harasawa M, Matsui N, Ogane N, Murakami M, Mikami M, Yanase T, Osamura RY. Granulosa cell tumor with activated mTOR-HIF-1alpha-VEGF pathway. J Obstet Gynaecol Res 2010; 36: 448-453. [Medline] 